\title{
Postganglionic Sympathetic Fiber
}

National Cancer Institute

\section{Source}

National Cancer Institute. Postganglionic Sympathetic Fiber. NCI Thesaurus. Code

C12650.

An axon that projects from a nerve cell body within a sympathetic ganglion and innervates an effector cell within a target organ. Postgang lionic sympathetic fibers use norepinephrine and acetylcholine as transmitters, sometimes with peptide cotransmitters. 